\title{
Regulating Global Drug Problems
}

Link to publication record in Manchester Research Explorer

\section{Citation for published version (APA):}

Seddon, T. (2013). Regulating Global Drug Problems. (RegNet Research Paper; No. 2013/06).

\section{Citing this paper}

Please note that where the full-text provided on Manchester Research Explorer is the Author Accepted Manuscript or Proof version this may differ from the final Published version. If citing, it is advised that you check and use the publisher's definitive version.

\section{General rights}

Copyright and moral rights for the publications made accessible in the Research Explorer are retained by the authors and/or other copyright owners and it is a condition of accessing publications that users recognise and abide by the legal requirements associated with these rights.

\section{Takedown policy}

If you believe that this document breaches copyright please refer to the University of Manchester's Takedown Procedures [http://man.ac.uk/04Y6Bo] or contact uml.scholarlycommunications@manchester.ac.uk providing relevant details, so we can investigate your claim.

\section{OPEN ACCESS}


Australian

National

University

\section{REGNET RESEARCH PAPER}

No. $2013 / 6$

Regulating Global Drug Problems

Toby Seddon

Regulatory INSTITUtions Network (REgNet) 
This RegNet Research Paper Series is published electronically by the Regulatory Institutions Network (RegNet) at the Australian National University.

Please visit our website to find out more about the work we do at regnet.anu.edu.au

(C) Copyright is held by the author or authors of each research paper. Electronic and paper copies may be made of a research paper, but its format may not be altered in any way without the author's permission.

Note: The views expressed in each paper are those of the author or authors of the paper. They do not represent the views of the series editor, RegNet, or the Australian National University.

Series Editor: Dr Jeroen van der Heijden

Production Editor: Ms Rhianna Gallagher

Please forward any feedback, submissions or requests to: rhianna.gallagher@anu.edu.au or

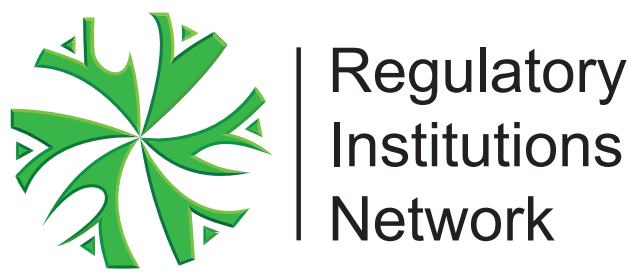




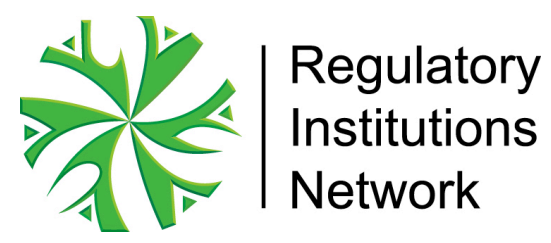

RegNet Research Paper No. 2013/6

\section{Regulating global drug problems}

Toby Seddon

This working paper was first presented at the RegNet @10 Conference, at The Australian National University, Canberra, in March 2011.

\begin{abstract}
The problems associated with the global drug trade are amongst the most challenging and intractable of all those facing policy-makers. The global drug prohibition system is widely acknowledged as a costly and counterproductive failure, not only presiding over a massive expansion of the problem but also causing a range of damaging side-effects, notably fuelling organised crime. The need for new thinking has never been more evident. It is argued that current arguments for drug policy reform, whilst highly effective at critiquing prohibition, are nevertheless based on a false understanding of the nature of markets and regulation. This paper sets out an alternative constitutive conception of drug control which not only provides a better basis for challenging prohibition but also a more fruitful framework for developing an alternative approach. It is suggested that the regulation perspective outlined in this paper represents a new paradigm for addressing the challenges presented by global psychoactive commerce in the early twenty-first century.
\end{abstract}

\section{Keywords}

Drugs, psychoactive substances, regulation, markets, globalization 


\section{INTRODUCTION}

The consumption of psychoactive substances of one kind or another is a practice that stretches back deep into human history and has been found in most cultures and societies around the world (Siegel 1989; Goodman et al 1995; Porter and Teich 1995; Courtwright 2001). Acknowledging this longue durée is important - the human desire for intoxication is not a symptom of a spiritual malaise peculiar to today's world, as some commentators claim, a sign, for example, of the 'dark side' of globalized consumer capitalism (e.g. Alexander 2010). Nevertheless, it is also evident that the twentieth century was a particularly interesting period in this long history, with significant global change unfolding, both in relation to patterns of consumption and to drug control strategies. The aim of this paper is to engage with the contemporary legacy of these developments and, in particular, with the legal and policy challenge they present us with at the beginning of the twenty-first century. The central argument that will be made is that to meet this challenge we need a paradigm shift in our thinking and that a regulatory perspective offers the most fruitful way forward (Seddon 2007, 2010a, 2010b:100-121, 2013; Ritter 2010).

The need for a radical new approach to drugs has grown more sharply evident in recent years. There is now a considerable consensus that the global prohibition system has been a disastrous and costly failure (e.g. Global Commission on Drug Policy 2011). Indeed, it is actually very difficult to find any serious policy thinker or commentator arguing for the status quo. Yet, curiously, at the same time as support for prohibition has ebbed away, the debate about drug policy reform has become narrower and more repetitive, centring almost exclusively around discussion of the merits of calls for decriminalisation or legalization (e.g. Rolles 2009; MacCoun and Reuter 2011). It will be argued that the apparently radical character of these calls masks the fact that beneath the polarised prohibition-legalization debate lies a shared understanding of the nature of markets and their regulation. We need to bore an opening in this increasingly ossified debate through which we can start to see an alternative way of dealing with the drug question.

It will be argued that for an anatomist of drug policy to create such an opening - a policy foramen - will require a fundamental rethinking of the nature and potential of drug control. The paper begins by briefly tracing the historical development of contemporary global drug problems. The central argument is then developed by proceeding through three steps. First, an analysis of how drug control has usually been conceived and understood and the ways in which this has been problematic. This involves a critique of the case for change made by the 
drug policy reform movement. Second, the construction of an alternative understanding of drug control, drawing on a constitutive conception of regulation (Shearing 1993). Third, an examination of some directions for drug policy that follow from this constitutive perspective. In conclusion, it will be suggested that viewing global drug law and policy through a regulatory lens of this kind represents a new paradigm for thinking about this most 'wicked' of twenty-first century problems (Rittel and Webber 1973).

\section{GLOBAL ILLICIT DRUG PROBLEMS: THE LEGAL AND POLICY CHALLENGE}

At the beginning of the twenty-first century, we face some stark facts about the global drug situation. Although the drug trade is legally prohibited - within a framework of United Nations Conventions to which over 160 countries have signed up - it is estimated that there could be as many as 300 million drug users around the world, representing $6 \%$ of the global population aged between 16 and 64 (UNODC 2012; Degenhardt and Hall 2012). The majority of this total, approximately two thirds, are cannabis smokers but there are also approaching 39 million problem users of opiates, cocaine or amphetamines and up to 21 million injectors (Degenhardt and Hall 2012). It has been estimated that the annual size of this global market at the retail level could be as much as US $\$ 320$ billion (UNODC 2005) or around $1 \%$ of global GDP ${ }^{1}$.

The global disease burden associated with this level of drug use is substantial ${ }^{2}$, particularly in relation to the transmission of HIV, hepatitis and other blood-borne viruses. Excluding subSaharan Africa, injecting drug use accounted for approximately one third of all new HIV infections reported globally in 2010 (UNODC 2012:15). Around one in every 100 deaths amongst the 15-64 population is attributable to drug use (UNODC 2012:7). Non-health harms are equally significant. For some substances, notably heroin and cocaine, involvement in drug production has largely been concentrated in poorer countries and has exacerbated development issues, as we see very clearly, for example, in Afghanistan, currently the world's largest producer of opium (Byrd 2008; UNODC 2010; Caulkins et al 2010). Transit countries - places which lie on drug trading routes - also typically suffer serious harms, including violence, organised crime and the corruption of officials (e.g. Fenopetov 2006). The latest example of this is the emergence of parts of West Africa as transit hubs for cocaine trafficking between Latin America and Europe, a development which has been profoundly damaging for the region (UNODC 2007; Carrier and Klantschnig 2012). In richer, developed 
countries, the drug trade carries a different but equally troubling set of problems, notably the impact on crime (Bennett et al 2008) and inequalities (Stevens 2011:13-32).

This is a dismal picture. Assuming the purpose of a prohibition system is to eliminate the market, we might draw the blunt conclusion that it has been a spectacular failure (Room and Reuter 2012). Indeed, there is strong evidence that the very substantial increases in expenditures on drug law enforcement that we have seen in recent decades have actually been associated with a trend of declining drug prices, the precise opposite of what would be expected if enforcement action was being at all effective as a market-reduction instrument (Basov et al 2001; Macoun and Reuter 2011: 66-67). From this perspective, arguments that are sometimes floated that the drug trade would be even bigger without prohibition (e.g. UNODC 2012:93) - that is, that it has helped to 'keep the lid on' the problem - can be read simply as haggling about the degree of the system's failure. But the situation is even worse than this. As several drug policy analysts have persuasively argued, prohibition is not only ineffective, it actually causes significant harms in its own right (Wood et al 2009). The damaging impact of prohibition on levels of violence in drug markets (Goldstein et al 1992), involvement of organised crime in the drug trade (Ferragut 2012) and on aspects of public health (Bluthenthal et al 1999; Friedman et al 2006) has been extensively and depressingly documented.

By any measure, this is a sorry state of affairs: we have spent enormous amounts of money to prohibit a trade, only to see that trade in fact spread and grow across the world and, along the way, we have caused significant ancillary problems for global health, security and poverty. Furthermore, we have known about this failure not just for years but for decades. Herbert Packer (1968:332-3), for example, in his classic 1968 book The Limits of the Criminal Sanction, after listing a familiar set of failings associated with the US drug laws commented that a 'clearer case of misapplication of the criminal sanction would be difficult to imagine'3. In a similar vein, Alfred Lindesmith (1965) had argued a couple of years earlier in 1965 for the dismantling of the drug prohibition regime and its replacement with a 'genuine medical system'. We are faced, then, with a puzzle: how have we ended up in this deeply unsatisfactory situation?

The first part of an answer involves going back just over one hundred years to the beginning of the twentieth century. More specifically, the story begins in Shanghai in 1909 when delegates from thirteen countries gathered together to discuss the opium problem in China and elsewhere (Stein 1985:50-67). This meeting turned out to be the starting point for the 
assembly of what we now describe as the global drug prohibition system (Bruun et al 1975). The novelty of this system was the bringing together for the first time of a sub-group of psychoactive substances within an international control system. The drivers for prohibition were complex and diverse but centred around the foreign policy and economic interests of certain powerful nations, most notably the US but also Britain and other Western European countries and, to a lesser extent, China (Courtwright 2001; Bruun et al 1975; Bewley-Taylor 1999; Nadelmann 1990:502-513; van Duyne and Levi 2005). This is important because it tells us that power, politics and trade have always been at the heart of prohibition, even when policy discourses have emphasised other concerns like health or morality. In this sense, a work like Alfred McCoy's (1972) The Politics of Heroin - which uncovered CIA involvement in the heroin trade in Southeast Asia in the 1960s, driven by US foreign policy interests documents a strategy that falls squarely within the parameters and logic of prohibition rather than being an aberration ${ }^{4}$.

After the Shanghai meeting, a series of further gatherings culminated in the signing of the International Opium Convention in The Hague in 1912 which set a template for drug control for the next several decades. The trajectory of the control regime over the course of the century followed a path of progressive extension, broadening and hardening up, especially in the post-1945 period (Bayer and Ghodse 1999). For many, it was the passing of the United Nations Single Convention on Narcotic Drugs in 1961 (Lande 1962; Lowes 1966; Waddell 1970) which truly marked the onset of today's global drug prohibition system with its distinctively criminalizing and punitive orientation (Bewley-Taylor 1999; Seddon 2010b), encapsulated in US President Nixon's famous declaration in 1971 of a 'war on drugs'. As we will see, in an important conceptual sense, this prohibitionist 'war' can be understood not as an attempted solution to the contemporary drug problem but rather as part of its production.

The second part of an answer involves understanding the significant changes that unfolded over the twentieth century in the size, spread and nature of the illicit drug trade. Painting with a broad brush, we can identify three broad phases of development. The first, covering roughly the first four decades of the century, saw the trade in these newly-controlled substances remain relatively small and stable and largely confined to the US, Europe and China (van Duyne and Levi 2005:24-28). The second phase, starting in the 1950s and 1960s, involved the emergence of what we would now term recreational drug-taking, largely related to the rise of new youth cultures associated with music and fashion. This phase mainly occurred in the US and Western Europe and centred initially on cannabis, amphetamines and LSD (Gfroerer and Brodsky 1992), extending later on in the 1980s and 
90s to cocaine, ecstasy and other stimulants (Reuband 1995). The third phase, overlapping a little with the second, has seen the stabilisation of consumption in the 'old' markets of the West, at the same time as the geographical spread of the drug trade into parts of the world which had previously largely avoided it, starting with Eastern Europe (Csemy et al 2002), moving across parts of Asia (Kulsudjarit 2004; McKetin et al 2008) and, most recently, into Africa (Dewing et al 2006; Carrier and Klantschnig 2012), culminating in today's globalised drug market $^{5}$ (Stares 1996; UNODC 2012:66-69).

We might see these twentieth-century developments, at least in part, as linked to a more general phenomenon associated with contemporary capitalism. As Levi-Faur (2005) and others (Braithwaite 2008) have argued, we live in a world of global regulatory capitalism in which both markets and regulation have become more vibrant, driven by a powerful globalising dynamic. This has certainly been the broad direction of travel for the international drug trade and drug control system over the last half-century: more market activity, more (prohibitive) rules, more (attempted) enforcement. Braithwaite $(2005,2008)$ argues that a feature of this spread of dynamic markets with a global reach is that it engenders 'markets in vice' as much as it does 'markets in virtue'. As he puts it, 'markets do not make moral judgements. If they work more efficiently, they will more efficiently produce bads as well as goods' (2008:198). We can observe a very recent example of this in the proliferation in the last few years of new ways of manufacturing, marketing and selling novel stimulant drugs, where distribution via the internet, and using the virtual currency Bitcoin for payment, has fuelled the very rapid creation of new markets which largely sidestep the existing international drug control and law enforcement systems (UNODC 2013). In this sense, one way to reconceptualise drug policy is to view it as a typical twenty-first century regulatory problem in which the challenge is to devise strategies that can flip these vibrant markets from vice to virtue, that is, from markets that generate social harms to markets that can produce public goods (Braithwaite 2005, 2013). It is this reconceptualisation that this paper seeks to develop. But first we must examine existing conceptions and understandings of drug control.

\section{DRUG CONTROL AND MARKET ORDERING}

The most powerful and pervasive mode of drug policy critique is the well-known set of arguments for the decriminalisation or legalization of illicit drugs. The nub of these arguments, as I have already noted, is that prohibition fails to eliminate either supply or demand and simply pushes the drug trade into the hands of criminal organisations and 
gangs. As a result, not only is it ineffective, it also creates considerable secondary harms in relation to security, safety and public health, whilst fuelling criminality and corruption. The solution, from this perspective, is to sweep away the global prohibition regime and introduce a new legal framework for drug control that is not based on criminalisation.

The case for drug policy reform along these lines is strong and has been articulated many times over the last few decades, perhaps most persistently and incisively by Ethan Nadelmann (e.g. Nadelmann 1988, 1989, 1992, 2004), founder of the Drug Policy Alliance, and by the UK-based NGO Transform (e.g. Rolles et al 2006; Rolles 2009, 2010) ${ }^{6}$. In the last couple of years, a series of high-profile reports have pushed the reform agenda right to the forefront of public debate (e.g. Global Commission on Drug Policy 2011; Home Affairs Committee 2012). It is certainly hard to refute the central claim that the prohibition paradigm is fundamentally flawed and in fact causes more problems and suffering than it alleviates or prevents. To add further weight to the argument, there have also been some recent empirical studies, notably of the decriminalization policy in Portugal (Hughes and Stevens 2010; Hughes and Stevens 2012), which have tended to support the case for reform (see also Rosmarin and Eastwood 2012). Coherent or evidence-based counter-arguments are decidedly thin on the ground.

It might seem somewhat perverse then to start from a critique of the arguments for reform. But, as I will show, this critique can in fact direct us to the analytical heart of the problem and point to a way out of the present intellectual and policy impasse. Let me begin with the crux of the matter for the reformers, as pithily expressed by Rolles (2010:128) in an influential piece in the British Medical Journal:

Non-medical drug markets can remain in the hands of unregulated criminal profiteers or they can be controlled and regulated by appropriate government authorities.

The choice presented here is between unregulated markets which can be exploited by criminals or state-regulated markets which can be controlled by governments. Put in those terms, the 'correct' public policy choice is obvious and Rolles makes his case very persuasively. A similar analysis is offered by Nadelmann (1992:95) in a classic article in which he argues that drug control policies can be thought of as 'arrayed along a spectrum, with the strictly prohibitionist and highly punitive at one end, the unregulated free market at the other end, and a wide array of regulatory policies in the middle'. 
These are undoubtedly persuasive arguments. Yet, in some quite significant ways, they are based on assumptions that fly in the face of what we actually know about regulation and market ordering. The reformist position draws on what Shearing (1993) describes as a control conception of regulation. This is founded on the idea that market ordering is a 'natural', autonomous process that tends to optimise both individual and collective goods, as in Adam Smith's metaphor of the 'invisible hand'. For some, the market is always best at promoting the public interest and should be left alone. Others believe that intervention is almost always necessary to temper the excesses of the free market. Spread out in the middle between these two poles or extremes are those who believe that market ordering sometimes works well but also fails in some areas. The regulatory debate is then simply about when external controls are required to correct glitches in the normal self-ordering process of the market.

This is the terrain of the classic regulation-deregulation debate and its familiar conflicts or questions. Do we need to set markets free? Or do we need controls on markets to ensure the public interest is served? From this control perspective, regulation is a form of 'external ordering' (Shearing 1993:69) that can control the operation of market forces. It is, in other words, an interference with markets, a negative or constraining activity. This may be viewed as a good or bad thing, depending on where one stands on the regulation-deregulation debate, but the essential claim about what regulation is and what it does is accepted right across the divides of that debate.

This helps us to understand better the reformist position on drug markets. According to this view, the failure of prohibition derives from its location too far towards an extreme pole of the continuum. There is, in other words, a need to move closer towards the middle of the spectrum of regulatory options. Prohibitionists, on the other hand, hold that the problem is the failure to enforce fully and properly the external ordering imposed by the prohibition regime. Paradoxically, both extremes of the continuum tend to be characterised as leading to markets that are de facto not regulated at all: Rolles (2010:128) describes the criminal markets created by prohibition as 'unregulated', whilst Nadelmann (1992:95) uses the same term for the free markets that would result from wholesale legalization. We have, in this sense, an inverted u-curve model of regulation (see Figure 1$)^{7}$. 


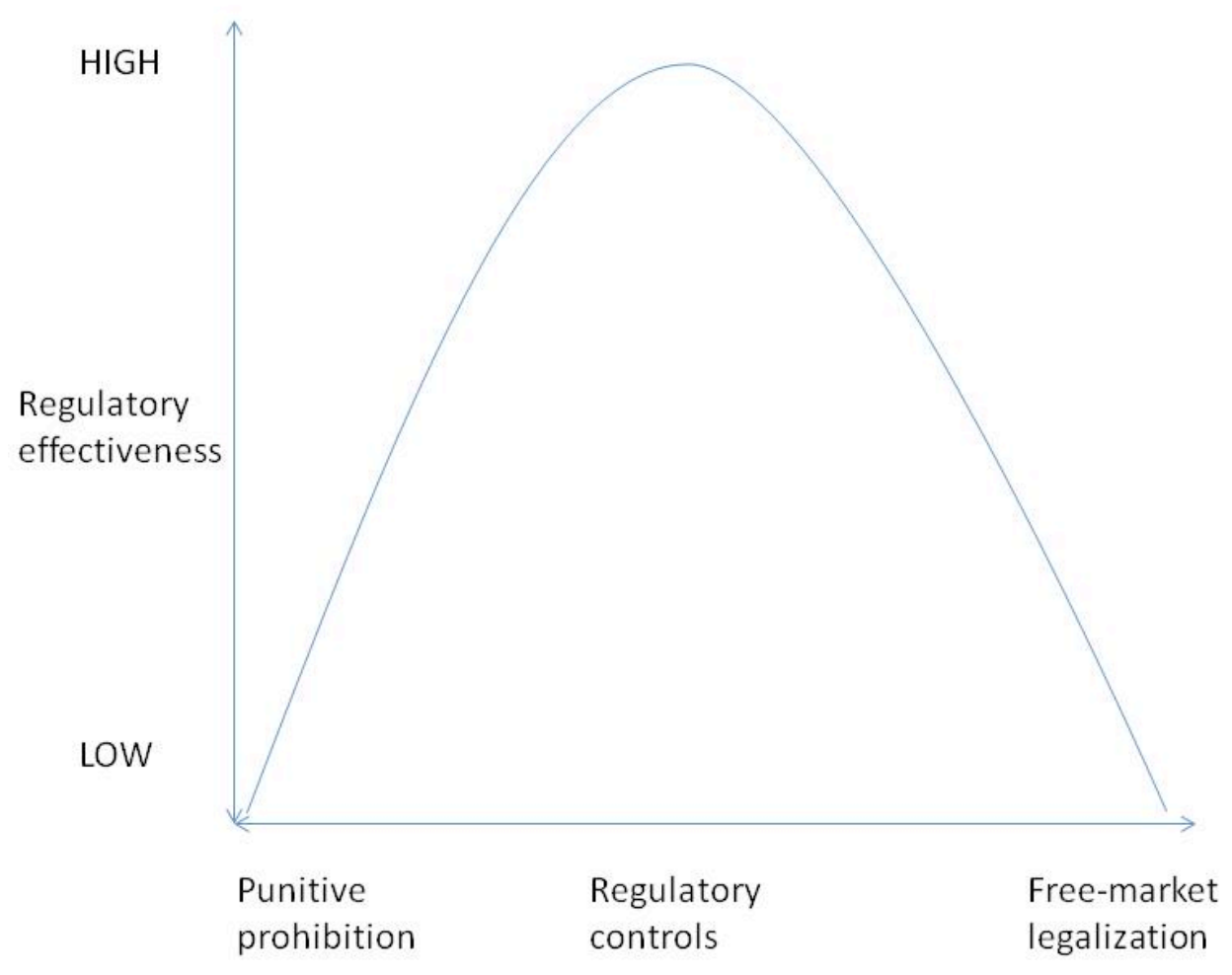

Figure 1: Inverted u-curve model of drug control

This way of viewing the drug policy debate reveals the rather counter-intuitive insight that both the prohibitionist and reformist positions in fact share the same set of assumptions about market ordering and regulation. Despite the radical-sounding arguments of the drug policy reform position, it 'draws on the same root image as the [...] argument it seeks to refute' (Shearing 1993:71). The debate is solely about what type of external ordering - or regulation - is required for the drug trade. This is part of the reason why the debate has become so ossified and repetitive. It also points us towards an analytical way forward: it is this 'root image' of market regulation that needs to be challenged.

Before turning to this task in the next section, it is worth picking apart a little further the control conception of regulation, as it used in drug policy debates. Going back to the model in Figure 1, at each extreme of the curve, there is understood to be a 'market failure' in which it is possible to conceive of regulation failing to 'bite' to such an extent that the market resembles an unregulated one. It is failure of this kind which generates what Ogus (1994:2954) describes as a 'public interest' case for market intervention or regulation and this is, in effect, the animating principle for much of the drug policy reform movement. Put simply, for 
reformists the current approach fails to regulate the market in a way that serves our collective social interests.

But what exactly does market failure mean? Zerbe and McCurdy (1999) observe that the concept is usually defined in terms of the unintended production of what economists call externalities, that is, negative, and typically non-monetary, effects of markets operating inefficiently. They argue, however, that virtually all markets in the real world are inefficient to some degree and therefore produce externalities. A more fruitful approach, they suggest, is to use the concept of transaction costs. These can be thought of as introducing friction into a market (Zerbe and McCurdy 1999:566). From a purist free-market perspective, this creates unwanted inefficiencies. But friction can also be understood as potentially a useful regulatory instrument. The deliberate and targeted introduction of degrees of friction into different parts of a market can be a means of shaping or directing behaviour in desired directions, slowing down or speeding up specific areas of activity within the market.

This idea of transaction costs, or friction, helps us to understand further the limitations of the control conception of drug control. If we take the free-for-all legalization model, the extreme right-hand end of the curve in Figure 1, the argument is that this fails because it minimises transaction costs to such an extent that consumption would likely increase to a socially undesirable level, with the further threat that such a market would be ripe for exploitation by suppliers using marketing techniques to stimulate significant new demand. The market would be too efficient, in a sense, rather than failing. This is a slightly paradoxical idea from the viewpoint of economic theory but is a result of the socio-political judgement that the market in substances like cocaine or cannabis is intrinsically undesirable, an argument to which I will return $^{8}$. But it is the other end of the curve that is more interesting. Here, the reformist position could be seen as arguing that punitive prohibition introduces so much friction into the market that in fact an alternative criminal market flourishes, producing along the way an extensive set of externalities. At this point, the control conception of regulation breaks down. What this analysis of prohibition reveals is that regulation is not simply an external constraint applied to a market that has a (quasi-)independent or prior existence, rather regulation helps to produce or constitute the market. And so the assumption that the governmental enterprise in this field is simply about finding the 'right' type of balance between market and state ordering - a notion which underpins the current debate about drug policy reform - turns out to be fundamentally flawed. 


\section{A CONSTITUTIVE CONCEPTION OF DRUG CONTROL}

The idea that regulation is productive or constitutive rather than simply negative or constraining is partly a Foucauldian one (Foucault 1977:194). It is also linked to a line of thought within economic sociology (Granovetter 1985; Cotterrell 2013) which can be traced back to Polanyi's (1944) The Great Transformation and his thesis on the 'embeddedness' of markets. In one of the most insightful accounts from this perspective, Shearing (1993) sets out what he terms a constitutive conception of regulation. His starting point is the recognition that markets do not just exist, that is, they are not 'natural phenomena' (1993:71) created out of unmediated human interaction. Markets do not have a pure pre-regulatory existence that is just given. They are instead created out of regulatory frameworks and regimes and shaped by prior and ongoing allocations of resources. Hence the very idea of market deregulation is a chimera. In blunt terms, 'there is no escape from the necessity of regulation [...] no unconstituted market to which to turn nor is there market ordering that will relieve us of the task of regulation' (1993:71).

This helps to illuminate why the usual understanding of drug control, as described in the previous section, is wrong. The two ends of the curve in Figure 1 are not points at which the drug market becomes 'unregulated'. They are distinctive regulatory regimes which constitute the market in particular ways. The central problematic of the drug policy reform debate - that we need to choose between having an illegal or legal drug market - is quite simply false, at least as presented in that dichotomous form. An example illustrates this point well. The trade in cigarettes is legal but in recent years there has been a major rise in smuggling and bootlegging across Europe and elsewhere (van Duyne 2003; von Lampe 2010). This criminal dimension to the market has been produced to a great extent through taxation policies which have resulted in large differentials in duty between countries, in effect incentivising crossborder smuggling. In other words, the regulatory strategy has constituted the market in a particular way. This example also helpfully reminds us that criminality can be associated with a market even where trade in a particular commodity is ostensibly legal.

This raises a critical conceptual question which Beckert and Wehinger (2011) put like this: what exactly do we mean when we describe a market as illegal? They identify four different types of illegal market:

Type 1) where the production, provision or distribution of a commodity is illegal (e.g. child pornography); 
Type 2) where the market exchange of otherwise licit commodities is illegal (e.g. selling human organs);

Type 3) where a product or commodity has been stolen or forged (e.g. selling of counterfeit art);

Type 4) where legal rules or standards have been violated in the production of a licit commodity (e.g. selling food produced/prepared in breach of legal hygiene standards).

Evidently, then, there is no simple policy choice to be made between having a legal or illegal market. Indeed, not only are there several different forms of market illegality, it is clear that legal and illegal aspects are often intertwined within markets, as the example above of the cigarette trade illustrates. Other examples show further complexities. If we take heroin, for instance, in many respects this is clearly traded within a Type 1 illegal market and indeed we might view it as an exemplar of an illicit commodity. But in some parts of the world, most notably the UK, heroin (diamorphine) is also a staple of medical practice, used for pain relief and palliative care, particularly with cancer patients (Gossop et al 2005). This means that there is a parallel regulatory regime for its licit production, distribution and consumption for the purpose of legitimate medical care. Globally, many countries have an involvement in the licit production of opium for medicines, with India currently the largest producer (Paoli et al 2009). In the UK, the pharmaceutical company Macfarlan Smith Ltd has the sole licence to grow opium poppies, which it does on several sites in southern England, in order to produce a range of opiates, including diamorphine ${ }^{9}$. To add a further twist, should any of this licit diamorphine or heroin leak outside the medical system, as inevitably happens on occasion, at that point we could then describe its market exchange as operating in an illegal market, one lying perhaps somewhere between Type 1 and Type 2.

This all points to the complexity of the matter and the limited analytical value in thinking about markets in this context as either legal or illegal, in any simple sense. How then should we understand drug control from a constitutive perspective? Shearing (1993:72) argues that one way to think about it is in terms of the idea of regulatory space first developed by Hancher and Moran (1989) who suggest that regulation can be conceived as taking place in a space in which there may be multiple regulatory schemes and influences (see also Scott 2001). According to Shearing (1993:72), to focus solely on state regulation is therefore a 'peculiar and conservative' response to most regulatory problems, because it represents an approach which is 'content to leave the shape of the regulatory space in question essentially unchanged and to concern itself exclusively with the presence or absence of the state' within that space. For drug control, the policy debate is even narrower: it is not even about the 
presence or absence of the state but rather about what form the state regulatory presence should take (criminalization, legalization etc).

Adapting from Shearing (1993:77), we can now draw out three key principles for a constitutive conception of drug control. Each challenges aspects of conventional thinking about drug policy reform and, as we will see in the next section, also points towards some new directions for the development of policy.

First, a constitutive conception will involve abandoning the 'notion of market ordering as a basis for regulatory thinking' (Shearing 1993:77). In other words, we will have to leave behind our attachment to the idea that the policy task is to find the right balance of controls or constraints on otherwise self-ordering drug markets. It will understand that these markets are constituted within and by the shape and contours of the regulatory space in which they are located and that however we describe our approach (e.g. prohibition or legalization) that regulatory space is never empty. Put simply, all regimes of regulation produce their corresponding drug markets.

Second, it will acknowledge that there are multiple (actual and potential) sources of regulatory influence that can occupy the regulatory space, going beyond law enforcement by the state. It is the 'conflicts and alliances' (Shearing 1993:77) between these multiple sources that should be the principal concern and the state has to be 'decentred' both for analysis and policy prescription (Black 2001; Rose and Miller 1992; Burris et al 2005). In other words, we have to start to look beyond the state for solutions to our drug problems.

Third, it will require a shift in focus away from concerns about rules, to a focus on goals. The 'essence of regulation is not compliance with rules but rather the constitution of an order understood as a state of affairs' (Shearing 1993:77). We need to imagine what the desired order or state of affairs looks like, instead of concentrating on creating new systems of rules and enforcement regimes. It is regulatory imagination that is required and this will have to extend beyond the law.

As a set of principles, these may be somewhat abstract. But, as I will now start to sketch out, this constitutive perspective also gives us a route map out of the 'stasis' (Reuter 2009:512) or ossification of current debates about drug policy reform, taking us well beyond arguments for (or against) decriminalisation and legalization. 


\section{NEW DIRECTIONS FOR DRUG POLICY: A REGULATION PERSPECTIVE}

From a constitutive perspective, the first policy question to ask is simple: what type of drug market do we want? Some will respond to this question by reasserting a desire to eliminate the trade in drugs entirely (drug policy types will recall the UN's now-abandoned slogan: "a drug-free world - we can do it!"). This opens up the whole thorny debate I have already touched on about whether these commodities are inherently undesirable within society. Ultimately, this is a political and cultural question and not one readily susceptible to arguments based on evidence. Fortunately, we do not need to resolve the debate because it is a matter of straightforward empirical observation that eliminating drugs has proved virtually impossible over the last 50 or more years, however much money we have spent on the task $^{10}$. The closest that anyone has come to effective elimination in the last century is probably in China, first of all with its opium suppression policy in the late Qing Dynasty and early Republic era between 1906 and 1917 (Windle 2013) and then in the first couple of decades of the communist People's Republic of China after its foundation in 1949 (Lu et al 2009:77-121). But given that these interventions were based on brutal and coercive mixes of land confiscation, property destruction, public torture and execution, most will not want to go down this kind of policy avenue. This brings us back then to the necessity of thinking seriously about what type of drug trade we actually want. The three principles outlined in the previous section start to lead us towards some new directions for policy.

The first principle, that regimes of regulation are constitutive of markets, requires us to think further about the concept of the drug trade. If we think of trade as the transfer of products or commodities, that is, as the linking of production with consumption (Smith 2009:12-21), then it is clear that there is not a single integrated global drug trading system, rather there are multiple regional systems, some of which are transnational but many of which are not (see note 5). It follows that we need to design regulatory regimes at the level of these trading systems. This leads to an essential but perhaps disorientating conclusion: it may now be time to discard the concept of 'drug policy' in favour of more substance-specific and contextuallyattuned approaches. The theoretical point is that the category of illicit drugs - just like those of 'over-the-counter' medicines or prescription drugs - is a regulatory construct associated with a specific regulatory regime ('prohibition') (Ruggiero 1999; Seddon 2010c). Substances that come under these labels actually have little in common, other than how they are regulated. In this sense, by using the terms 'drug' and 'drug policy', reformers risk failing to escape from the conceptual boundaries of the policy position they seek to critique and 
overturn: the concept of 'drugs' is inextricably bound up with the strategy of prohibition. Pushing the point, we might even say then that the notion of drug policy reform - of the kind espoused by Transform, the Drug Policy Alliance and others - is oxymoronic.

If we abandon the regulatory construct of 'drugs', we are faced with the need to determine which categories different substances should be assigned to. Taking cannabis as an example, there is obviously a range of possibilities. We could, for instance, classify it as an agricultural product or, alternatively, as an ingested consumable like food and drink. Or, we could view it as a general consumer product, no different from any other commodity that we buy, like televisions or lawnmowers. Or, we could class it as a 'sister' commodity to tobacco, smoked for pleasure but potentially carrying certain risks to health. We could even define it as a medicinal product. There are no doubt other possibilities. The central point is that each of these regulatory categories will lead to distinctive regulatory approaches which will constitute the market in particular ways. Again, there is no escape from the need to choose what type of market we want.

For most of these regulatory categories, there is a wealth of knowledge on how best to craft effective regulation. For example, for any substance classified as an agricultural product, we can draw on the rich and detailed insights from regulatory scholars like Smith (2009), Hutchens (2009) and many others which engage with the distinctive set of regulatory challenges associated with that category. We should not, however, be under any illusion that assigning a substance to one (or more) of these categories will by itself resolve all legal and policy difficulties. We need only think of the example of food regulation and its periodic crises and scandals to see that the challenges around harms, illegality and criminality remain substantial (see Croall 2012). Nevertheless, by moving beyond the regulatory construct of 'drugs', we open up a new vista of regulatory possibilities that is broader and richer than that offered by the options of decriminalization or legalization and, furthermore, on which there is a considerable bank of accumulated regulatory wisdom in the research and policy literatures.

The second principle, decentring the state in our thinking about policy, directs us to the question of how we should regulate. What are the tools and instruments we can introduce into the regulatory spaces in which these different markets are constituted? As noted above, to some extent, this question goes hand in hand with the issue of regulatory classifications. For example, a psychoactive substance categorized as a consumer product will tend to imply a particular menu of regulatory options. At a surface level, these options include standard consumer protection measures on labelling, product information, information disclosure and 
quality assurance, as well as mechanisms for redress in relation to product liability. Delving a little deeper, we can see that what is involved when we view matters through the lens of consumer product regulation is a multi-faceted regulatory mix which brings together state intervention with private law. As Collins $(1999,2004)$ argues, there is a productive 'collision' between public and private within the regulatory space, in which the capacity of private actors for reflexivity and responsiveness in their contractual practices is central to regulatory effectiveness. If we remain fixated on the state, we miss the significance of what private actors can do. Howells' (2011) detailed analysis of tobacco control from a consumer protection perspective is an instructive example of where this line of thinking might take us in terms of regulating some aspects of psychoactive commerce.

This also highlights the need to look at the multiple actors who can be involved. As Burris et al (2005:31-2) observe, early twenty-first century regulation involves a 'plurality of actors [...] forming more or less interconnected [regulatory] networks [...], a plurality of mechanisms [...] and rapid adaptive change'. State-centric models are simply inadequate for capturing the 'real world' complexity of ordering within contemporary social systems. Another example illustrates how this insight on the networked character of regulation can be used for policy purposes. The problem of the diversion and/or misuse of pharmaceutical products is far from new. From Benzedrine inhalers in the 1940s and 1950s (Jackson 1971) through to OxyContin in the last decade (Cicero et al 2005), this has proved a very difficult area to deal with effectively. Abuse of OxyContin, a synthetic slow-release opioid available on prescription, has become a particularly significant problem in the US since the late 1990s. Many policy analysts diagnose the issue there as deriving primarily from a failure of federal agencies to exert proper control over pharmaceutical companies (e.g. Griffin and Spillane 2013) and this is no doubt partly the case. But if we think about the 'plurality of actors' who could potentially be drawn into the regulatory endeavour, the possibilities and options multiply rapidly. A classic paper by Braithwaite (1993) on the regulation of the pharmaceutical industry sets out the multi-level 'web of controls' that can be applied in this sector: 'national regulatory enforcement, regional regulatory co-operation, international regulatory coordination, intrafirm regulation [...], interfirm self-regulation [...] and private regulation by product liability suits and consumer activism' (1993:16-17; see also Roemer-Mahler 2013). Thinking about a problem like OxyContin abuse solely or principally through the lens of federal law and policy will lead to myopic and narrow solutions that are ineffective.

The third principle, focusing on goals rather than rules and enforcement, turns our attention to perhaps the most fundamental policy question we have to address: what should we be 
trying to achieve? I have already dismissed the goal of eradicating the drug trade - perhaps too readily for some - but I think most would accept that would be a hopelessly unrealistic objective, even if it were desirable (which many would dispute). It is easy to rehearse some obvious policy aims - cutting mortality rates, reducing transmission of blood-borne viruses like HIV, lowering drug-related crime - but beyond such 'motherhood and apple pie' statements, it is harder to determine what order or state of affairs we should be trying to constitute. As Braithwaite (2000) has remarked, social scientists rarely take normative thinking - the development of 'ordered propositions about the way the world ought to be' (2000:87) - very seriously. But a constitutive conception of drug control requires us to engage our regulatory imagination on these difficult normative questions.

One of the most fruitful attempts to develop normative thinking from within a regulation perspective is the republican theory set out by Braithwaite and Pettit (1990; see also Pettit 1997). They propose a notion of civic freedom, or 'dominion', as the overarching goal for systems of regulation. Dominion provides a 'master value' or yardstick for balancing other values: the optimum regulatory mix is that which best advances dominion. Starting from this normative commitment, we can then approach issues like the allocation of substances to regulatory categories in these terms: can we be confident, for example, that treating cannabis as an agricultural product will increase dominion? If not, then we should not define it in that way. Criminalizing conduct, as we currently do so readily in this area, can only ever be justified if it can be shown to enhance civic freedom in a significant way. The more general point is that rather than making law enforcement one of the centerpieces of policy, we should be building serious normative thinking into our regulatory design right from the start. And this will involve engaging in a proper dialogue with citizens so that policy is the transparent outcome of deep contestation within deliberative democracies (Braithwaite 2008:199-207).

\section{CONCLUSION}

I should perhaps begin this conclusion by underlining a point that may have become less than clear in the preceding discussion. In arguing partly from a critique of the legalisation/decriminalisation movement, I do not mean to suggest that reform of the international legal framework will not be necessary or that the work of that movement has not been profoundly important within the global drug policy debate. Indeed, the critiques of prohibition developed by Nadelmann, Rolles and others have been so sharp that the case for maintaining the policy status quo has effectively been demolished. Although most 
mainstream politicians and policymakers still claim to support it, behind the scenes many are not so sure and the trend of former political leaders and police chiefs coming out in support of drug policy reform has become very marked in recent years.

Where the reform movement has been less effective is in explaining what a post-prohibition world would look like. Probably the best effort to date has been Transform's Blueprint document (Rolles 2009) which certainly contains some interesting ideas and has made a very useful contribution in moving the debate forward. But it also marks where I part company with the reform movement because it remains constrained by its basis in a control conception of regulation and hence is overly-fixated on law reform and state action. For all the reasons I have discussed in this paper, I think these will form only one part of a more progressive approach to the problems posed by global psychoactive commerce in the twenty-first century.

The regulation perspective that has been outlined in this paper represents a new paradigm for thinking about what has proved to be one of the hardest public policy challenges of the last fifty years. It provides a theoretical and conceptual framework both for diagnosing the problem and for developing new solutions. In an era of regulatory capitalism, it is regulatory theory that offers us the best intellectual toolkit for change ${ }^{11}$.

One line of objection to the type of approach set out in this paper is that it is politically unpalatable and therefore has little or no realistic prospect of ever becoming anything more concrete than an interesting idea. There is an element of truth to this - and indeed it arguably applies to the drug policy reform movement more broadly - but there are two grounds for optimism. First, there is some evidence that public opinion has started to turn against prohibition and that there is a growing willingness to at least listen to alternative policy propositions $^{12}$. Second, it is a view that arguably rests on an unduly restrictive understanding of the nature of the politics of policy-making in this area. As Paul-Emile (2010:694) astutely observes, drawing on Lessig (1995), when we assign a substance to a regulatory category, this is not a purely technical matter. These categories also serve to allocate 'specific meaning and significance' to a substance (2010:694). As Garland (1990) shows us in another context, this expressive, communicative dimension is important to grasp. If we conceive of regulation solely as an instrumental undertaking, we close our eyes to a significant aspect of what we are doing with law and policy in this area. So new strategies we might propose do not simply have to fit with or follow the prevailing political weather, they are also part of what makes that weather. Given the terrible failures of the current global prohibition system, we have a 
responsibility to seize the agenda in bolder and more imaginative ways that we have managed to over the last 50 or more years.

\section{NOTES}

1. For useful discussions of the difficulties in sizing the global drug market, see Reuter and Greenfield (2001) and Thoumi (2005).

2. The disease burden associated with illegal drugs is, however, considerably smaller than for tobacco and alcohol. See Lim et al (2013).

3. I am grateful to Steve Rolles at Transform for a reminder of this passage from Packer.

4. Similar analyses have been applied to other episodes in different parts of the world. McCoy (2010) himself has drawn parallels with the case of opium production in Afghanistan where, he argues, US foreign policy involvement over the last 35 years, initially triggered by the Soviet invasion in 1979, is critical to understanding Afghanistan's centrality to the world heroin trade today.

5. The drug trade is now 'global', in the sense that its traded commodities (cannabis, heroin, cocaine etc) are available in almost every part of the world. Arguably, it is not, however, a single globally-integrated market but rather a set of separate regional markets organised around production sources and trading routes. This distinction has been much debated by economists and in the globalization literature - Perraton (2001) provides a helpful guide. Its policy significance comes to the forefront particularly when considering how to reduce supply. For an interesting socio-historical review of the globalization of trade, see Chase-Dunn et al (2000).

6. Other prominent drug policy reform organisations that have made sustained contributions to the debate include Release (www.release.org.uk) and the Hungarian Civil Liberties Union (www.drogriporter.hu/en).

7. This model is adapted from one presented by Transform (2012:3) in their evidence to the UK Home Affairs Select Committee Inquiry into Drug Policy. 
8. This point is alluded to, in passing, by Zerbe and McCurdy (1999:565, fn 5).

9. Further information about Macfarlan Smith, including its historical involvement in the field dating back to the nineteenth century, is available on its website: www.macsmith.com.

10. Estimates of these costs are inevitably rough and ready but a recent report by the Count the Costs project suggests that at least US\$100 billion is spent each year globally on drug law enforcement (see: Count the Costs (2012) and www.countthecosts.org).

11. There are three particular influences on this paper that should be acknowledged. The first is the chapter on pharmaceutical regulation in the magisterial Global Business Regulation by Braithwaite and Drahos (2000). When I first began developing these ideas in 2006, this was my guiding text. The other two emerged shortly after, but entirely independently from, my own first contribution to this area (Seddon 2007): a wonderful short article by Ritter (2010) and an extremely insightful piece by legal scholar Paul-Emile (2010).

12. An Ipsos-MORI opinion poll commissioned by Transform in early 2013 found that $53 \%$ of the British population supported either the legalization of cannabis or the decriminalisation of its possession. An independent review of all policy options was supported by $67 \%$. Full poll data are available here: http://www.tdpf.org.uk/lpsos_MORI_TPDF_poll.pdf. 


\section{REFERENCES}

Alexander, B. (2010) The Globalization of Addiction: A study in poverty of the spirit. Oxford: Oxford University Press.

Basov, S., Jacobson, M. and Miron, J. (2001) 'Prohibition and the Market for Illegal Drugs' World Economics 2(4) 1-25.

Bayer, I. and Ghodse, H. (1999) 'Evolution of international drug control, 1945-1995' Bulletin on Narcotics LI (1 and 2) 1-17.

Beckert, J. and Wehinger, F. (2011) In the Shadow: Illegal Markets and Economic Sociology. MPIfG Discussion Paper 11/9. Cologne: Max Planck Institute for the Study of Societies.

Bennett, T., Holloway, K. and Farrington, D. (2008) 'The statistical association between drug misuse and crime: A meta-analysis' Aggression \& Violent Behavior 13 107-118.

Bewley-Taylor, D. (1999) The United States and International Drug Control, 1909-1997. London: Continuum.

Black, J. (2001) 'Decentring Regulation: Understanding the Role of Regulation and SelfRegulation in a "Post-Regulatory" World' Current Legal Problems 54 103-147.

Bluthenthal, R., Lorvick, J., Kral, A., Erringer, E. and Kahn, J. (1999) 'Collateral damage in the war on drugs: HIV risk behaviors among injection drug users' International Journal of Drug Policy 10 25-38.

Braithwaite, J. (1993) 'Transnational Regulation of the Pharmaceutical Industry' Annals of the American Academy of Political and Social Science 525 12-30.

Braithwaite, J. (2000) 'Republican theory and crime control' in: S. Karstedt and K.-D. Bussmann (eds) Social Dynamics of Crime and Control: New Theories for a World in Transition. Oxford: Hart.

Braithwaite, J. (2005) Markets in Vice, Markets in Virtue. Sydney: Federation Press. 
Braithwaite, J. (2008) Regulatory Capitalism: How it works, ideas for making it work better. Cheltenham: Edward Elgar.

Braithwaite, J. (2013) 'Flipping markets to virtue with qui tam and restorative justice' Accounting, Organizations and Society.

Braithwaite, J. and Drahos, P. (2000) Global Business Regulation. Cambridge: Cambridge University Press.

Braithwaite, J. and Pettit, P. (1990) Not Just Deserts: A Republican Theory of Criminal Justice. Oxford: Oxford University Press.

Bruun, K., Pan, L. and Rexed, I. (1975) The Gentlemen's Club: International Control of Drugs and Alcohol. Chicago: University of Chicago Press.

Burris, S., Drahos, P. and Shearing, C. (2005) 'Nodal Governance' Australian Journal of Legal Philosophy 30 30-58.

Byrd, W. (2008) Responding to Afghanistan's Opium Economy Challenge: Lessons and Policy Implications from a Development Perspective. Washington, DC: World Bank.

Carrier, N. and Klantschnig, G. (2012) Africa and the War on Drugs. London: Zed Books.

Caulkins, J., Kleiman, M. and Kulick, J. (2010) Drug Production and Trafficking, Counterdrug Policies, and Security and Governance in Afghanistan. New York: Center on International Cooperation, New York University.

Chase-Dunn, C., Kawano, Y. and Brewer, B. (2000) 'Trade Globalization since 1795: Waves of Integration in the World-System' American Sociological Review 65(1) 77-95.

Cicero, T., Inciardi, J. and Munoz, A. (2005) 'Trends in Abuse of OxyContin® and Other Opioid Analgesics in the United States: 2002-2004' Journal of Pain 6(10) 662-672.

Collins, H. (1999) Regulating Contracts. Oxford: Oxford University Press. 
Collins, H. (2004) 'Regulating Contract Law' in: C. Parker, C. Scott, N. Lacey and J. Braithwaite (eds) Regulating Law. Oxford: Oxford University Press.

Cotterrell, R. (2013) 'Rethinking 'Embeddedness': Law, Economy, Community' Journal of Law and Society 40(1) 49-67.

Count the Costs (2012) The Alternative World Drug Report: Counting the Costs of the War on Drugs. Bristol: Transform Drug Policy Foundation.

Courtwright, D. (2001) Forces of Habit: Drugs and the making of the modern world. Cambrige, MA: Harvard University Press.

Croall, H. (2012) 'Food, crime, harm and regulation' Criminal Justice Matters 90 16-17.

Csémy, L., Kubička, L. and Nociar, A. (2002) 'Drug Scene in the Czech Republic and Slovakia during the Period of Transformation' European Addiction Research 8 159-165.

Degenhardt, L. and Hall, W. (2012) 'Extent of illicit drug use and dependence, and their contribution to the global burden of disease' The Lancet 379 55-70.

Dewing, S., Plüdemann, A., Myers, B. and Parry, C. (2006) 'Review of injection drug use in six African countries: Egypt, Kenya, Mauritius, Nigeria, South Africa and Tanzania' Drugs: Education, Prevention and Policy 13(2) 121-137.

Fenopetov, V. (2006) 'The Drug Crime Threat to Countries Located on the 'Silk Road" China and Eurasia Forum Quarterly 4(1) 5-13.

Ferragut, S. (2012) Organized Crime, Illicit Drugs and Money Laundering: the United States and Mexico. International Security Programme Paper 2012/01. London: Chatham House.

Foucault, M. (1977) Discipline and Punish: The birth of the prison. London: Allen Lane.

Friedman, S., Cooper, H., Tempalski, B., Keem, M., Friedman, R. et al (2006) 'Relationships of deterrence and law enforcement to drug-related harms among drug injectors in US metropolitan areas' AIDS 20 93-99. 
Garland, D. (1990) Punishment and Modern Society: A Study in Social Theory. Oxford: Clarendon Press.

Gfroerer, J. and Brodsky, M. (1992) 'The incidence of illicit drug use in the United States, 1962-1989' British Journal of Addiction 87(9) 1345-1351.

Global Commission on Drug Policy (2011) War on Drugs: Report of the Global Commission on Drug Policy. http://www.globalcommissionondrugs.org/Report

Goldstein, P., Brownstein, H. and Ryan, P. (1992) 'Drug-related homicide in New York: 1984 and 1988' Crime \& Delinquency 38 459-476.

Goodman, J., Lovejoy, P. and Sherratt, A. (eds) (1995) Consuming Habits: Drugs in History and Anthropology. London: Routledge.

Gossop, M., Keaney, F., Sharma, P., and Jackson, M. (2005) 'The unique role of diamorphine in British medical practice: a survey of general practitioners and hospital doctors' European Addiction Research 11 76-82.

Granovetter, M. (1985) 'Economic Action and Social Structure: The Problem of Embeddedness' American Journal of Sociology 91(3) 481-510.

Griffin, O.H. and Spillane, J. (2013) 'Pharmaceutical Regulation Failures and Changes: Lessons Learned from OxyContin Abuse and Diversion' Journal of Drug Issues 43(2) 164175.

Hancher, L. and Moran, M. (1989) 'Organizing Regulatory Space' in: L. Hancher and M. Moran (eds) Capitalism, Culture and Economic Regulation. Oxford: Oxford University Press.

Home Affairs Committee (2012) Drugs: Breaking the Cycle. London: House of Commons.

Howells, G. (2011) The Tobacco Challenge: Legal Policy and Consumer Protection. Farnham: Ashgate.

Hughes, C. and Stevens, A. (2010) 'What can we learn from the Portuguese decriminalisation of illicit drugs?' British Journal of Criminology 50(6) 999-1022. 
Hughes, C. and Stevens, A. (2012) 'A resounding success or a disastrous failure: Reexamining the interpretation of evidence on the Portuguese decriminalisation of illicit drugs' Drug and Alcohol Review 31(1) 101-113.

Hutchens, A. (2009) Changing Big Business: The Globalisation of the Fair Trade Movement. Cheltenham: Edward Elgar.

Jackson, C. (1971) 'The amphetamine inhaler: A case study of medical abuse' Journal of the History of Medicine 26 187-196.

Kulsudjarit, K. (2004) 'Drug Problem in Southeast and Southwest Asia' Annals of the New York Academy of Sciences 1025 446-457.

Lande, A. (1962) 'The Single Convention on Narcotic Drugs, 1961' International Organization 16(4) 776-797.

Lessig, L. (1995) 'The Regulation of Social Meaning’ University of Chicago Law Review 62(3) 943-1045.

Levi-Faur, D. (2005) 'The Global Diffusion of Regulatory Capitalism' Annals of the American Academy of Political and Social Science 598 12-32.

Lim, S., Vos, T., Flaxman, A., Danaei, G. et al (2013) 'A comparative risk assessment of global burden of disease and injury attributable to 67 risk factors and risk factor clusters in 21 regions, 1990-2010: a systematic analysis for the Global Burden of Disease Study 2010' The Lancet 380(9859) 2224-2260.

Lindesmith , A. (1965) The Addict and the Law. Bloomington, Indiana: Indiana University Press.

Lowes, P.D. (1966) The Genesis of International Narcotics Control. Geneva: Libraire Droz.

Lu, H., Miethe, T. and Liang, B. (2009) China's Drug Policies and Practices: Regulating Controlled Substances in a Global Context. Farnham: Ashgate. 
MacCoun, R. and Reuter, P. (2011) 'Assessing Drug Prohibition and Its Alternatives: A Guide for Agnostics' Annual Review of Law \& Social Science 7 61-78.

McCoy, A. (1972) The Politics of Heroin in Southeast Asia. London: HarperCollins.

McCoy, A. (2010) 'Can Anyone Pacify the World's Number One Narco-State? The Opium Wars in Afghanistan' << http://www.tomdispatch.com/blog/175225/>> [Last accessed: 03/05/13]

McKetin, R., Kozel, N., Douglas, J. Ali, R. et al (2008) 'The rise of methamphetamine in Southeast and East Asia' Drug and Alcohol Review 27(3) 220-228.

Nadelmann, E. (1988) 'The Great Drug Debate: The case for legalization' Public Interest 92 3-31.

Nadelmann, E. (1989) 'Drug prohibition in the United States: costs, consequences and alternatives' Science 245(4921) 939-947.

Nadelmann, E. (1990) 'Global prohibition regimes: the evolution of norms in international society' International Organization 44(4) 479-526.

Nadelmann, E. (1992) 'Thinking Seriously About Alternatives to Drug Prohibition' Daedalus 121(3) 85-132.

Nadelmann, E. (2004) 'Criminologists and Punitive Drug Prohibition: To Serve or To Challenge?' Criminology \& Public Policy 3(3) 1001-1010.

Ogus, A. (1994) Regulation: Legal Form and Economic Theory. Oxford: Hart.

Packer, H. (1968) The Limits of the Criminal Sanction. Stanford, CA: Stanford University Press.

Paoli, L., Greenfield, V. and Reuter, P. (2009) The World Heroin Market: Can Supply Be Cut? Oxford: Oxford University Press. 
Paul-Emile, K. (2010) 'Making Sense of Drug Regulation: A Theory of Law for Drug Control Policy' Cornell Journal of Law and Public Policy 19 691-740.

Perraton, J. (2001) 'The global economy - myths and realities' Cambridge Journal of Economics 25 669-684.

Pettit, P. (1997) Republicanism: A Theory of Freedom and Government. Oxford: Oxford University Press.

Polanyi, K. (1944) The Great Transformation: The Political and Economic Origins of Our Time. Boston: Beacon Press.

Porter, R. and Teich, M. (eds) (1995) Drugs and Narcotics in History. Cambridge: Cambridge University Press.

Reuband, K. (1995) 'Drug use and drug policy in Western Europe: Epidemiological findings in comparative perspective' European Addiction Research 1(1-2) 32-41.

Reuter, P. (2009) 'Ten years after the United Nations General Assembly Special Session (UNGASS): assessing drug problems, policies and reform proposals' Addiction 104 510-517.

Reuter, P. and Greenfield, V. (2001) 'Measuring Global Drug Markets: How good are the numbers and why should we care about them?' World Economics 2(4) 159-173.

Rittel, H. and Webber, M. (1973) 'Dilemmas in a General Theory of Planning' Policy Sciences 4 155-169.

Ritter, A. (2010) 'Illicit Drugs Policy Through the Lens of Regulation' International Journal of Drug Policy 21(4) 265-270.

Roemer-Mahler, A. (2013) 'Business conflict and global politics: The pharmaceutical industry and the global protection of intellectual property rights' Review of International Political Economy 20(1) 121-152.

Rolles, S. (2009) After the War on Drugs: Blueprint for Regulation. Bristol: Transform Drug Policy Foundation. 
Rolles, S. (2010) 'An alternative to the war on drugs' British Medical Journal 341:c3360.

Rolles, S., Kushlick, D. and Jay, M. (2006) After the War on Drugs: Options for Control. Bristol: Transform Drug Policy Foundation.

Room, R. and Reuter, P. (2012) 'How well do international drug conventions protect public health?' The Lancet 379(9810) 84-91.

Rose, N. and Miller, P. (1992) 'Political power beyond the State: problematics of government' British Journal of Sociology 43(2) 173-205.

Rosmarin, A. and Eastwood, N. (2012) A Quiet Revolution: Drug Decriminalization Policies in Practice Across the Globe. London: Release.

Ruggiero, V. (1999) 'Drugs as a password and the law as a drug: discussing the legalisation of illicit substances' in: N. South (ed) Drugs: Cultures, Controls and Everyday Life. London: Sage.

Scott, C. (2001) 'Analysing Regulatory Space: Fragmented resources and institutional design' Public Law 329-353.

Seddon, T. (2007) 'The regulation of heroin: Drug policy and social change in early twentiethcentury Britain' International Journal of the Sociology of Law 35(3) 143-156.

Seddon, T. (2010a) 'Regulating markets in vice' Criminal Justice Matters 80 6-7.

Seddon, T. (2010b) A History of Drugs: Drugs and freedom in the liberal age. Abingdon: Routledge.

Seddon, T. (2010c) 'Let’s Not Talk About Drugs' Drugs and Alcohol Today 10(3) 21-23.

Seddon, T. (2013) 'Regulating Health: Transcending Disciplinary Boundaries' Health Care Analysis 21 43-53. 
Shearing, C. (1993) 'A Constitutive Conception of Regulation' in: P. Grabosky and J.

Braithwaite (eds) Business Regulation and Australia's Future. Canberra: Australian Institute of Criminology.

Siegel, R. (1989) Intoxication: Life in the pursuit of artificial paradise. New York: E P Dutton.

Smith, F. (2009) Agriculture and the WTO: Towards a New Theory of International Agricultural Trade Regulation. Cheltenham: Edward Elgar.

Stares, P. (1996) Global Habit: The Drug Problem in a Borderless World. Washington, DC: Brookings Institution.

Stein, S.D. (1985) International Diplomacy, State Administrators and Narcotics Control: The Origins of a Social Problem. Aldershot: Gower.

Stevens, A. (2011) Drugs, crime and public health: The political economy of drug policy. Abingdon: Routledge.

Thoumi, F. (2005) 'The Numbers Game: Let's all guess the size of the illegal drugs industry!' Journal of Drug Issues 35(1) 185-200.

Transform (2012) Submission to the Home Affairs Select Committee Inquiry into Drug Policy. Bristol: Transform Drug Policy Foundation.

United Nations Office on Drugs and Crime (UNODC) (2005) World Drug Report 2005. Vienna: United Nations.

United Nations Office on Drugs and Crime (UNODC) (2007) Cocaine Trafficking in West Africa: The threat to stability and development. Vienna: United Nations.

United Nations Office on Drugs and Crime (UNODC) (2010) Afghanistan Opium Survey 2010. Vienna: United Nations.

United Nations Office on Drugs and Crime (UNODC) (2012) World Drug Report 2012. Vienna: United Nations. 
United Nations Office on Drugs and Crime (UNODC) (2013) The Challenge of New Psychoactive Substances. Vienna: United Nations.

van Duyne, P. (2003) 'Organizing cigarette smuggling and policy making, ending up in smoke' Crime, Law \& Social Change 39 285-317.

van Duyne, P. and Levi, M. (2005) Drugs and Money: Managing the drug trade and crimemoney in Europe. London: Routledge.

von Lampe, K. (2010) 'The Illegal Cigarette Trade' in: M. Natarajan (ed) International Crime and Justice. Cambridge: Cambridge University Press.

Waddell, I. (1970) 'International Narcotics Control’ American Journal of International Law 64(2) 310-323.

Windle, J. (2013) 'Harms caused by China’s 1906-1917 opium suppression intervention’ International Journal of Drug Policy.

Wood, E., Werb, D., Marshall, B., Montaner, J. and Kerr, T. (2009) 'The war on drugs: a devastating public-policy disaster' The Lancet 373 989-990.

Zerbe, R. and McCurdy, H. (1999) 'The Failure of Market Failure' Journal of Policy Analysis and Management 18(4) 558-578.

Toby Seddon

ManReg: The Manchester Centre for Regulation \& Governance

School of Law

University of Manchester

UK

toby.seddon@manchester.ac.uk 